\title{
ENERGY UTILIZATION AND WATER REQUIREMENTS OF CAPTIVE MYOTIS THYSANODES AND MYOTIS LUCIFUGUS (CHIROP'IERA)
}

\author{
MICHAEL J. O'FARRELL, EUGENE H. STUDIER \\ and WILLIAM G. EWING* \\ Institute of Scientific Research New Mexico, Highlands University, \\ Las Vegas, New Mexico 87701
}

(Received 1 October 1970)

\begin{abstract}
Ten captive Myotis thysanodes ingested an average of $5.05 \mathrm{kcal} /$ day and egested $0.47 \mathrm{kcal} /$ day with a mean energy utilization of 90.8 per cent.

2 . One captive $M$. lucifugus ingested $4.15 \mathrm{kcal} /$ day and egested $0.37 \mathrm{kcal} /$ day with an energy utilization of $91 \cdot 2$ per cent.

3. $M$. thysanodes gained an average of $2.77 \mathrm{~cm}^{3} /$ day of water and lost an average of $2.86 \mathrm{~cm}^{3} /$ day. This represents a water turnover of almost half the total body water.

4. The $M$. lucifugus gained $1.97 \mathrm{~cm}^{3} /$ day of water and lost at least $1.47 \mathrm{~cm}^{3} /$ day representing a water turnover of about one third of the total body water.

5. It is suggested that for small mammals in general that the energy utilization approaches or exceeds 90 per cent efficiency.
\end{abstract}

\section{INTRODUCTION}

In CONJUNCTION with physiological studies of Myotis in autumn prior to their hibernation, we were able to determine the energy utilization and water requirements of ten captive fringe-tailed bats, Myotis thysanodes and one captive little brown bat, $M$. lucifugus occultus, over a period of 10 consecutive days. Heretofore, caloric utilization has been reported for only two species of bats: a single hoary bat, Lasiurus cinereus (Brisbin, 1966) and a single silver-haired bat, Lasionycteris noctivagans (Neuhauser \& Brisbin, 1969).

During the autumn, Myotis thysanodes and M. lucifugus deposit fat (Ewing et al., 1970) and alter their metabolic responses to lowered environmental temperatures by adopting partial or complete heterothermy (O'Farrell \& Studier, 1970). It is therefore of interest to know the efficiency with which these Myotis can assimilate energy from the food they consume during this time of the year.

\section{MATERIALS AND METHODS}

All bats used in this study were adult females collected in late September, 1969, from a maternity roost in the attic of Montezuma Seminary, Montezuma, San Miguel County, New Mexico. Each animal was kept at room temperature $\left(18-24^{\circ} \mathrm{C}\right)$ in a 1-pint ice cream

* Present address: Department of Biology, University of New Mexico, Albuquerque, New Mexico 87106. 
carton fitted with a window-screen lid. Individual bats were hand-fed mealworm larvae (Tenebrio spp.) daily between 1800 and $2100 \mathrm{hr}$; drinking water was available ad lib. from a $2 \mathrm{~cm}^{3}$ pipette during the feeding period. Hand-feeding was begun several days before the collection of data to eliminate those bats which would not eat in captivity. During the experimental period, the weight of food and volume of water consumed were determined daily for each bat. Feces from the previous day were collected before the bat was returned to its container.

Ten $10 \mathrm{~g}$ samples of mealworms were dried to constant weight for determination of water content. These samples were then pooled and pulverized, and portions were taken for determination of caloric content with a Parr oxygen bomb calorimeter (Model 1300). Fecal samples were individually dried and bombed. Caloric utilization was determined by dividing the difference between $\mathrm{kcal}$ ingested and $\mathrm{kcal}$ egested by the total $\mathrm{kcal}$ ingested.

\section{RESULTS}

\section{Energy content of food}

Tenebrio larvae in this study were found to be $46.56 \%$ water (S.E. $\bar{x}=0.69$ ) with a caloric content of $3.52 \mathrm{kcal} / \mathrm{g}$ weight (S.E. $\bar{x}=0.02$ ). This is a considerably higher figure than the $2.33 \mathrm{kcal} / \mathrm{g}$ live wt. reported by Neuhauser $\&$ Brisbin (1969).

\section{Energy balance}

During the experimental period, the $10 M$. thysanodes gained weight from an initial $8.06 \mathrm{~g}$ (S.E. $\bar{x}=0.06$ ) to a final weight of $8.74 \mathrm{~g}$ (S.E. $\bar{x}=0.93$ ). The single $M$. lucifugus gained weight from 7.57 to $8.20 \mathrm{~g}$. The weight gained probably represented fat deposition (Ewing et al., 1970).

The $M$. thysanodes ingested daily an average of $5.05 \mathrm{kcal}$ and egested $0.47 \mathrm{kcal}$, representing an energy utilization of $90 \cdot 8$ per cent. The $M$. lucifugus ingested $4.15 \mathrm{kcal}$ daily and egested $0.37 \mathrm{kcal}$, representing an energy utilization of 91.2 per cent. Comparison with other bats is presented in Table 1.

TABLE 1-INGESTED AND EGESTED ENERGY, ENERGY UTILIZATION AND DAILY ENERGY REQUIREMENT FOR Myotis thysanodes, Myotis lucifugus, Lasiurus cinereus* AND Lasionycteris noctivagans $\dagger$

\begin{tabular}{|c|c|c|c|c|}
\hline & $\begin{array}{c}\text { Energy } \\
\text { ingested } \\
\text { (kcal/day) }\end{array}$ & $\begin{array}{c}\text { Energy } \\
\text { egested } \\
\text { (kcal/day) }\end{array}$ & $\begin{array}{c}\text { Energy } \\
\text { utilization } \\
(\%)\end{array}$ & $\begin{array}{l}\text { Daily energy } \\
\text { requirement } \\
\text { (kcal/g) }\end{array}$ \\
\hline Myotis thysanodes & $\begin{array}{c}5.05 \pm 0.27 \\
(3.88-6.57)\end{array}$ & $\begin{array}{c}0.47 \pm 0.03 \\
(0.28-0.63)\end{array}$ & $\begin{array}{l}90 \cdot 8 \pm 0 \cdot 4 \\
(88 \cdot 4-92 \cdot 8)\end{array}$ & 0.60 \\
\hline Myotis lucifugus & $4 \cdot 15 \pm 0.67$ & $0.37 \pm 0.10$ & $91 \cdot 2 \pm 1 \cdot 5$ & 0.53 \\
\hline Lasiurus cinereus* & $\begin{array}{l}7 \cdot 13 \pm 1 \cdot 48 \\
(5 \cdot 47-10 \cdot 13)\end{array}$ & $\begin{array}{c}0.63 \pm 0.32 \\
(0.00-1.18)\end{array}$ & $\begin{array}{l}91 \cdot 0 \pm 4 \cdot 6 \\
(84 \cdot 6-100 \cdot 0)\end{array}$ & $0 \cdot 30$ \\
\hline Lasionycteris noctivagans $\dagger$ & $\begin{array}{l}4 \cdot 86 \pm 1 \cdot 45 \\
(1 \cdot 77-7 \cdot 51)\end{array}$ & $\begin{array}{c}0.47 \pm 0.20 \\
(0.09-0.89)\end{array}$ & $\begin{array}{l}88 \cdot 6 \pm 6 \cdot 85 \\
(73 \cdot 5-98 \cdot 2)\end{array}$ & 0.50 \\
\hline
\end{tabular}

* Data from Brisbin (1966).

$\dagger$ Data from Neuhauser \& Brisbin (1969).

The figures for the Myotis are \pm standard error of the mean, while the others are \pm standard deviation. The range is indicated in parentheses. 


\section{Water balance}

The daily sources of water gain for $M$. thysanodes were $0.66 \mathrm{~cm}^{3}$ in food, $0.63 \mathrm{~cm}^{3}$ in drinking water, and an estimated $1.48 \mathrm{~cm}^{3}$ in metabolic water (O'Farrell \& Studier, 1970), resulting in an average total water gain of $2.77 \mathrm{~cm}^{3} /$ day.

A rough estimate of water loss per day can be made by assuming a daily loss of $2.66 \mathrm{~cm}^{3}$ due to evaporation (Studier, 1970 ), $0.08 \mathrm{~cm}^{3}$ in urine production (Studier, unpublished), and $0 \cdot 12 \mathrm{~cm}^{3}$ in feces (assuming feces to be 50 per cent water). The total estimated water loss, $2.86 \mathrm{~cm}^{3} /$ day, approximates the water gain. This water turnover represents almost half the total body water.

Similarly, $M$. lucifugus daily gained $0.55 \mathrm{~cm}^{3}$ in food, $0.86 \mathrm{~cm}^{3}$ in drinking water, and $0.56 \mathrm{~cm}^{3}$ in metabolic water, representing a total water gain of $1.97 \mathrm{~cm}^{3}$ / day. Estimated daily water losses were $1.39 \mathrm{~cm}^{3}$ evaporated, $0.08 \mathrm{~cm}^{3}$ fecal, and an unknown amount in the urine, for a total water loss of at least $1.47 \mathrm{~cm}^{3}$ per day. This water turnover represents about one third of the total body water.

\section{DISCUSSION}

From an examination of Table 1 it appears that the species are comparable in various respects when standardized to body weight. Efficiency of energy utilization of these bats is similar to that in the least shrew, Cryptotis parva, 90.1 per cent and several species of rodents (Barrett, 1969). It appears that for small mammals in general that the energy utilization approaches or exceeds 90 per cent efficiency.

Based upon an average metabolic rate of $4.56 \mathrm{~cm}^{3} \mathrm{O}_{2} / \mathrm{g}$ per $\mathrm{hr}$, STPD, for homeothermic $M$. thysanodes in autumn (O'Farrell \& Studier, 1970), we calculate that this species must assimilate $4.39 \mathrm{kcal} /$ day to maintain caloric balance. The observation that $4.58 \mathrm{kcal} /$ day were assimilated, indicates that a positive energy balance was maintained. This agrees well with the observed weight gain and the needed fat deposits preparatory to hibernation.

The individual $M$. lucifugus assimilated $3.78 \mathrm{kcal} /$ day but required only 1.34 $\mathrm{kcal} /$ day based on a metabolic rate of $1.47 \mathrm{~cm}^{3} \mathrm{O}_{2} / \mathrm{g}$ per hr, STPD (O'Farrell \& Studier, 1970). This metabolic rate was observed for heterothermic $\boldsymbol{M}$. lucifugus in the fall. It is probable that in captivity the animal became homeothermic and consequently our estimate of metabolic rate would be too low. However, this bat gained weight throughout the study period and indeed maintained a positive energy balance.

Acknowledgements-We thank Mr. Mark Martin for his assistance in the laboratory. This study was financed by a grant from the Institute of Scientific Research, New Mexico Highlands University, Las Vegas.

\section{REFERENCES}

BaRRETt G. W. (1969) Bioenergetics of a captive least shrew, Cryptotis parva. F. Mammal. 50, 629-630.

BrisBin I. L., JR. (1966) Energy-utilization in a captive hoary bat. F. Mammal. 47, 719720. 
Ewing W. G., Studier E. H. \& O'Farrell M. J. (1970) Autumn fat deposition and gross body composition in three species of Myotis. Comp. Biochem. Physiol. 36, 119-129.

Neuhauser H. N. \& Brisbin I. L., JR. (1969) Energy utilization in a captive silver-haired bat. Bat Res. News 10, 30-31.

O'Farrell M. J. \& Studier E. H. (1970) Fall metabolism in relation to ambient temperatures in three species of Myotis. Comp. Biochem. Physiol. 35, 697-704.

Studier E. H. (1970) Evaporative water loss in bats. Comp. Biochem. Physiol. 35, 935-943.

Key Word Index-Chiroptera; bats; Vespertilionidae; Myotis thysanodes; water balance; energy utilization; Myotis lucifugus. 